\title{
Strategic Direction toward Internationalization Business and Management Education
}

\author{
Dyah Kusumastuti
}

\begin{abstract}
The growth of internationalization activities within higher education has become "an important issues" and "present wave" in the development of higher education. Internationalization strategy is needed in higher education to accelerate the transformation into internationalization effectively. The purpose of this study is to offer a strategic direction for the internationalization of a private university in Indonesia. Present a five elements framework for strategy design, which providing answer to five questions. Arenas: where will we be active? Vehicles: how will to get there? Differentiator: how will we win in the marketplace? Staging: what will be our speed and sequence of moves? And last, Economic logic: how will we obtain our returns? Through those elements, the creating strategic direction expected that internationalization could work efficiently and effectively. Finding of this study reveals that there are elevens clusters of organization capability that must be considered to achieve HE internationalization. Those clusters includes: clusters organization capability such as 1) Organization and Leadership; 2) Managing Quality Management System; 3) Student and Graduate; 4) Managing People at work; 5) Developing Curriculum; Learning Management System \& Academic Atmosphere; 6) Research, Professional Service, Community Service; 7) Cooperation \& Networking; 8) ICT Utilization; 9) Funding, Facility and Marketing Management; 10) Creating \& managing KMS (Knowledge Management System); 11) Recognize \& National and International Accreditation must be considered to achieve HE internationalization.
\end{abstract}

Index Terms-Strategic, direction, internationalization, higher education.

\section{INTRODUCTION}

In the new economy, competition is global, capital is abundant. Ideas are developed quickly and cheaply. People are willing to change jobs often and people are main source of sustainable competitive advantage. No organization is immune from the changing tides of economic, social, political and technological trends [1].

Thomas Friedman [2] discusses how technology and the Internet are "leveling the playing field, human resources play a significant role in the success of business corporate. Efficiency and higher productivity are not enough to guarantee the competitive advantage of any organization. Those which are likely to be successful will be companies that continuously produce new products and services and where innovation is a 'natural' ingredient of every role, will not simply counterbalance the removal of 'old' jobs with the creation of new ones. In building organizations capacity, the

Manuscript received April 25, 2013, revised June 20, 2013.

Dyah Kusumastuti is with Faculty of Business \& Management, Widyatama University, Bandung, Indonesia (e-mail: dyahk05@gmail.com). roles of Human Resource professionals is very important. $\mathrm{H}$. Linda argued that HR practitioners and line managers perceive the need to move on from 'traditional' roles, but the emerging roles are still being developed [3]. Open Knowledge is the energy of the $21^{\text {st }}$, the knowledge has led not only to the competition among employers but also institutions, and between countries that train the best brains.

Higher education institutions in $21^{\text {st }}$ are going through reforms regarding their mission and better use of their intellectual resources. Such of external factors which increasing economic role of knowledge, information technology and reduced public funding of higher education place huge pressure on institution to change [4]-[7].

N. Djanaeva [8] explained the particular benefits of internationalization by entering the world system of academic research and innovation, increasing the mobility of students, faculty, and staff, participating in international accreditation and credit transfer, revitalizing the nation's economy, democratizing the administration of colleges and universities. Broadening our understanding of academic freedom and learning new approaches to a range of issues and problems both academic and administrative.

J. Knight [4] described several reasons for internationalization such as Table I.

\section{A. Globalization and Internationalization of Business \& Management Education}

S. Noorda [9] argued that Business schools are among the best appreciated institutions of higher education worldwide. Past performance, however, does not guarantee future success. Ranking and accreditation are petrifying existing standards rather than promoting and rewarding dynamic development. The globalization of business and management education lead to various social and economic benefits to the business school's which has responsibilities to create graduates who have a global mindset, through more developed thinking, various practices are implemented, as well as international business and management. The globalization of management education is very important because it will ultimately shape globalization on people's lives in the future

There are various objectives of Internationalization on Education such as: Personnel development, Improvement of standards and quality of institutions or to strengthen the institutions, Market share, Higher income. Furthermore, there are some benefit of Internationalization such as more internationally oriented students and staff, Improved academic quality, Increased revenue generation, Opportunities for brain gain, Greater international understanding and solidarity, Innovations in curriculum, teaching and research, Foster "national and international" 
citizenship [5], [10], [11].

Based on those benefits, there are some reasons for globalization and internationalization of business education [4]- [11].

TABLE I : REASON FOR INTERNATIONALIZATION

\begin{tabular}{lll}
\hline \hline 1.Mobility and Exchanges for Student and Teachers & 6)Co-operation and Development & 11) Diversity source of Faculty and Students \\
2)Teaching and Research Collaboration & 7) Curriculum Development & 12) Regional Issues and Integration \\
3)Academic standards and Quality & 8) International and Intercultural Understanding & 13) International Student Recruitment \\
4)Research projects & 9) Promotion \& profile of Institution & 14) Diversity Income generation \\
5)Co-operation and Development & 10) Diversity source of Faculty \& Students & \\
\hline \hline
\end{tabular}

Source: J.Knight [4]

1) Businesses and business schools have a symbiotic relations, globalization creates conditions for the relationship between the business communities with business schools.

2) Changes in various economic indicators and illustrations used as inspiration for the development of management education.

3) The increasing number of students who studied business abroad creates the opportunity for developing a multinational business school with various patterns of international cooperation, especially developing global curriculum.

In developing international business education there various challenges and opportunities include : the quality of teachers, the need for embedding soft skills in the curriculum while maintaining analytical and knowledge in business, the impact of information and communication technologies in teaching and learning methods, financial balance and, alternative funding model for sustainable structures in order to achieve effective and efficient governance and make the right strategic choices that will allow the school to adapt for competitive pressures, and. the need for strengthening the school's reputation and brand building to secure long-term competitive position [5], [6], [10], [11].

\section{LITERATURE REVIEW}

\section{A. Creating Strategies Plan}

Knight and de Wit [4] discussed the strategies and activities that might needed for creating strategies internationalization. The strategies divided into two components of strategies. First, Program strategies are outbound student and staff mobility, curriculum development, foreign language study, joint research projects, joint programmers, scholarships and internships, extra-curricular activities, conferences and seminars attendance, and, inbound international students. Second strategies, Organizational strategies are commitment, support, and involvement of the staff, international orientation and initiatives, partnership agreements, formal communication channels, annual planning, budget and review, funding, policies, incentives and rewards [4],[5].

There are four basic approaches to develop internationalization 1) Activity approach: Bring international student body, developing or joining exchange programs. 2) Competency approach: Change in the knowledge, skills, interests, values, and attitudes of different groups of in the organization. 3) Ethos approach: Developing a culture and climate, which facilitates internationalization. 4) Process approach:

Developing an international aspect into not only academic aspects of the organization but also managerial aspect [4],

\section{[7].}

A strategy consist of an integrated set of choice, but it isn't a catchall for every important choice an executive face as Fig. 1 below portrayed our feedback arrows and other indicators that great strategies are iterative, loop thinkers. Four keys are not following a sequential process, but rather in achieving a robust, reinforced consistency among the elements of the strategy itself [12].

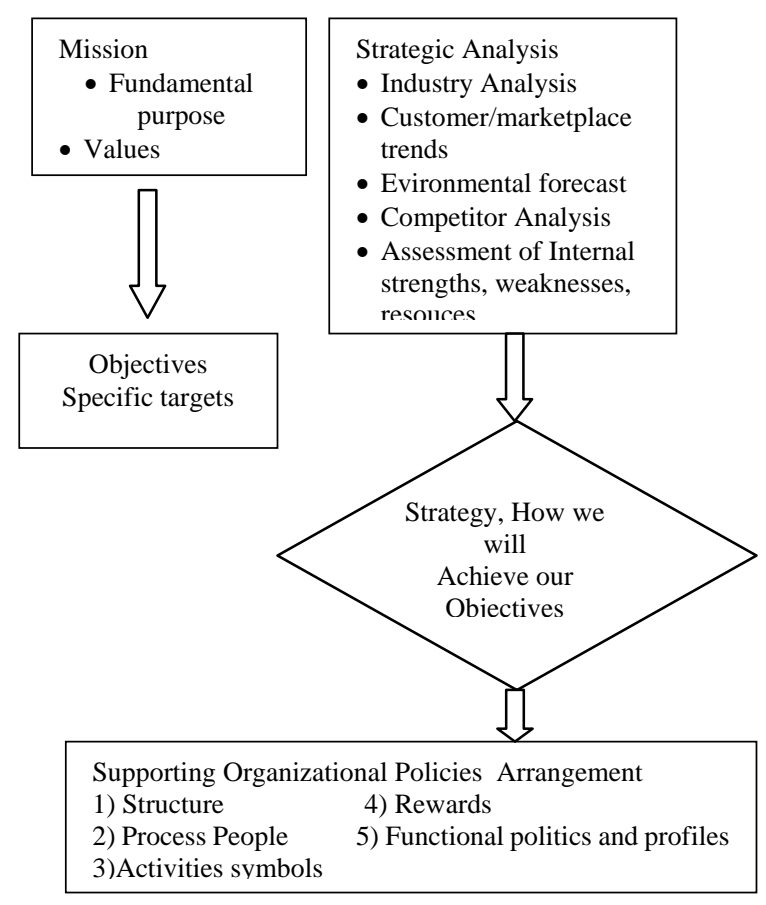

Fig. 1. Putting strategy in Its place

(Source: Donald C. Hambrick \& James W. Frederickson [12]

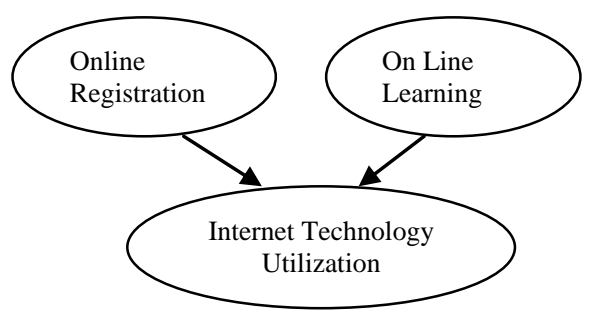

Fig. 2. Cluster similar capabilities into One capabilities group

Donald C. Hambrick \& James W. Frederickson, [12] arguing that the strategy design has five important elements shown in Fig. 3.

To develop those five elements strategy, there are needs for reviewing the strategy objectives for each mission that to achieve internationalization. Building block strategy followed by identification of resources \& organization Capabilities/ competencies needed, shown in Fig. 4. 


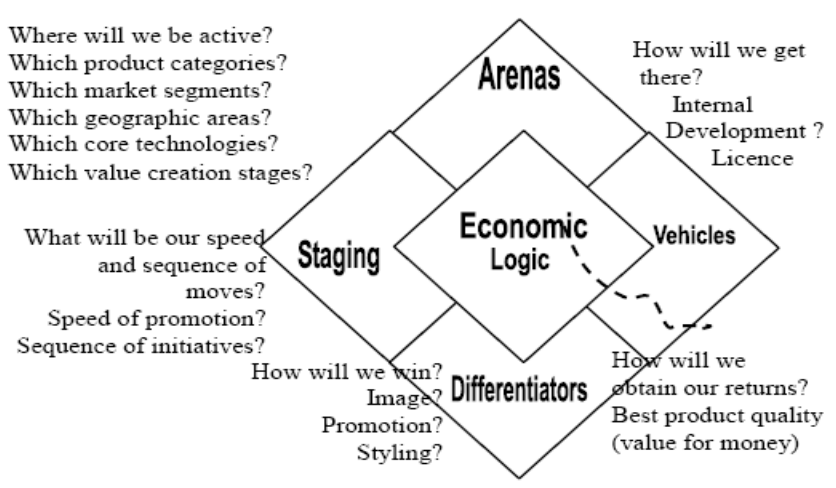

Fig. 3. The five major elements of strategy Source: Donald C. Hambrick \& James W. Frederickson [12]

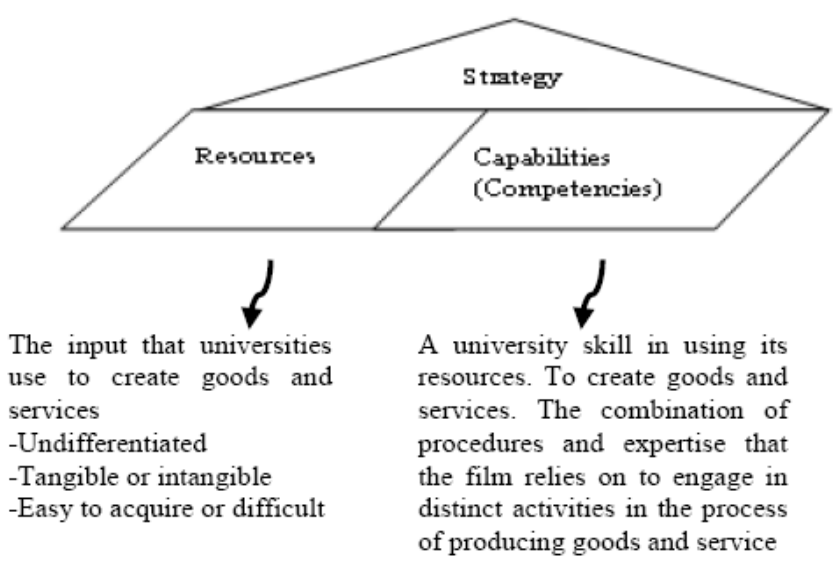

Fig. 4. Building block of strategy

\section{A. Arenas}

Area (study program, service, geographic markets, technology, etc) in which a organization participates, Arenas: where will be active? In these elements, we will enter for internationalization. For instance the Internationalization for student both outbound also inbound. Arenas is important to be as specific as possible categories product such as competency, market segments, as well as the value-adding stages (e.g., design program education, learning process, labor market). In choosing arenas, the strategist needs to show not only where the internationalization aspect will be active, but also how much emphasis will be place on each.

\section{B. Vehicles}

Means for entering new arenas (e.g. through acquisitions, alliances, internal development, etc). How we entering and work in arena that we chosen? Technology can be used, cooperation with another university, internal development also the using of IT in process of internationalization. The strategist also needs to decide how to get there concern those arena above; value-creation stage should be the result of deliberate strategic choice.

\section{Differentiators}

Feature or attribute of a company's product or service (e.g. image, customization, technical superiority, price, quality and reliability) that helps to win the competition in the marketplace. What are differentiation with arenas and the selected vehicle in terms of educational service product? A strategy should specify not only where will be active (arenas) and how it will get there (vehicles), but also how the firm will win in the marketplace-how it will get customers to come its way.

\section{Staging}

Timing and place of strategic moves, this substance-cries out for decisions on a fourth element- staging, or the speed and sequence of major moves to take in order to heighten the likelihood of success. Most strategies do not call for equal, balanced initiatives on all fronts at all times. Instead, usually some initiatives must come first, followed only then by others, and then still others.

\section{E. Economic Logic}

Means by which a firm will earn a profit or value by implementing a strategy. How we will obtain our return? At the heart of a business, strategy must be a clear idea of how profits will be generated - not just some profits, but profits above the organization cost of capital. It is not enough to vaguely count on having revenues that are above costs. Unless there's a compelling basis for it, customers and competitors. The most successful strategies have a central economic logic that serves as the fulcrum for profit creation .

\section{F. Methodology}

This Study used Business \& Management Faculty of a private university as Sample, which has an A-level accreditation from the National Accreditation Body. Then, do Self-evaluation and SWOT analysis through 7 (seven) aspect, choosing focus of internationalization and developing vision, mission and translate to the strategy elements such as arenas - vehicles- Differentiators - Stages - economic Logic, identification of organization capability needed, developing strategy Map and action plan

\section{RESULT}

The Results of Strategy plan toward Internationalization Business \& Management Faculty shown such as:

1) Based on self assessment and SWOT analysis through 7 aspects in business \& management Faculty shown in Table II, found that problems statement and what should be improved in institution, through factors LRAISE are such Leadership, Relevancy, Academic Atmosphere, Internal Management, Sustainability, Efficiency \& Productivity [13].

TABLE II: STRENGTH, WEAKNESS, OPPORTUNITY, THREAT (SWOT) FROM SELF ASSESSMENT OF FACULTY BUSINESS AND MANAGEMENT

\begin{tabular}{|c|c|c|c|c|c|c|c|c|}
\hline \multirow{2}{*}{ No } & \multirow{2}{*}{ Problem statement } & \multicolumn{7}{|c|}{ Factors relevant to the root problems } \\
\hline & & Aspects & $\mathrm{L}$ & $\mathrm{R}$ & A & I & S & $\mathrm{E}$ \\
\hline 2 & $\begin{array}{l}\text { Vision, mission, Objectives and goals of study } \\
\text { program not anticipate the external environment of } \\
\text { business education in the future. } \\
\text { The policy from top management not clearly define }\end{array}$ & $\begin{array}{l}\text { (A) } \\
\text { Vision, Mission, Objectives \& } \\
\text { Goals }\end{array}$ & $\mathrm{V}$ & V & $\mathrm{V}$ & $\mathrm{V}$ & $\mathrm{V}$ & \\
\hline & & & $\mathrm{V}$ & & $\mathrm{V}$ & $\mathrm{V}$ & & \\
\hline
\end{tabular}


$1 \quad$ The faculty policy did not encourage creativity

Quality assurance need to be enhanced so that every process is Creating Value

The heterogeneous of student need to be prepared for their readiness to learn in international environment.

E Learning needs to be developed as a strategic factor for internationalization success.

3 Motivating student to enhance their knowledge

4 Utilizing alumni in creating Internship place for fresh graduate
HRM for Faculty member as Knowledge Worker Evaluate and develop the curriculum periodically to match the graduates competency with the industry needs or users

2 system that utilize IT , LMS not developed

No academic atmosphere which motivate students to learn. Students interest to go to the library still low.

Financial management need to developed

(University Funding source, from Fund Endowment)

ICT for back office \& external \& Internal relation Cooperation with business association, user, other Business school, and Free trade association need to be developed

Innovative Reserch System that relevant to business need to be developed.

Community work / Professional service still in individual level

(B) Organization, Leadership, Quality Assurance Management System

(C)

Students and graduates

(D)HRM

(E) Curzriculum, Learning\&Academic atmosphere

(F) Funding

(G) Research , (Community service\&Cooperation, ICT

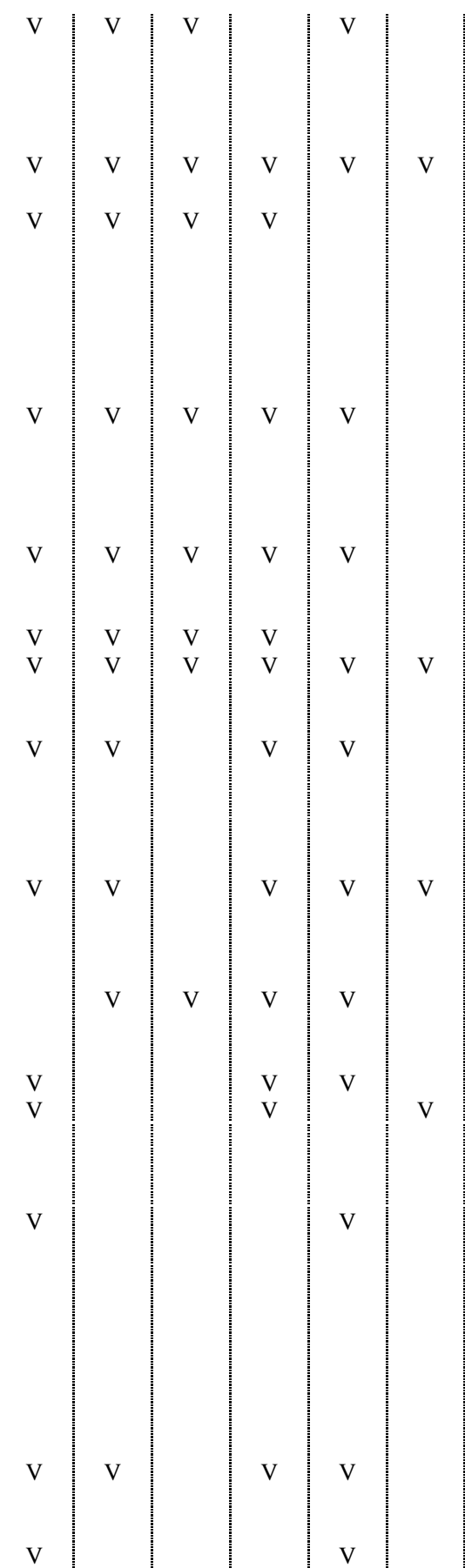

Source : Faculty Self Assessment, L = Leadership, R = Relevancy, A = Academic Atmosphere, I = Internal Management, S = Sustainability, E = Efficiency \& Productivity

2) Based on SWOT analysis and review of Internationalization of Business education Strategy design has five important elements such: A) Arenas: where will be actives. B) Vehicles: how will get there?
C) Differentiations: How will we win in the marketplace? D) Creating and Developing Vision, Mission, Quality objectives and Values System as Table III. 4) Economic logic: How will we obtain our return? 5) staging: what will be our speed and sequence of moves?, as shown in Table III, [12], [14]-[17].

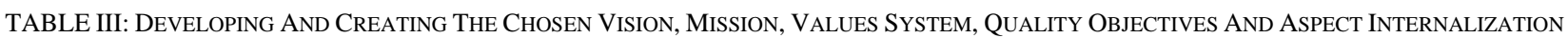

\begin{tabular}{|c|c|}
\hline Vision: & $\begin{array}{l}\text { Become World Class Service Education in School of Business \& Management in providing place to learn and } \\
\text { practice innovative business and management to be implemented in community based on noble values }\end{array}$ \\
\hline Mission: & $\begin{array}{l}\text { 1) Providing a learning experience that encourages Creating high impact applied knowledge 2) Encourage } \\
\text { contribution to the quality of life 3) Sharpening leadership 4) Leading entrepreneurship }\end{array}$ \\
\hline Values: & Value system: encourage Innovation, global mind, Embrace Diversity \\
\hline $\begin{array}{l}\text { Quality } \\
\text { Objectives: }\end{array}$ & $\begin{array}{l}\text { Quality objectives : 1)One of } 30 \text { graduates become entrepreneurs or are employed by global } \\
\text { organization/companies within two year after graduation, 2) one research per faculty member per year at average } \\
\text { 3) } 10 \% \text { active students have international experience during the study in Faculty Business \& Management 4) }\end{array}$ \\
\hline
\end{tabular}


Excellence stakeholder satisfaction

Internationalization Choosing or arenas:
1) Providing a learning experience that encourages Creating high impact applied knowledge 2) Encourage contribution to the quality of life 3) Sharpening leadership 4) Leading corporate entrepreneurship, Vehicles : ICT utilization, cooperation \& Networking, Staging : time frame 4 years, Differentiation : Reimage organization \&graduate Competency and Economic logic that will impact customer value, graduates that work in global companies and as knowledge worker

Source : Design based on SWOT Analysis

3) Steps of developing Strategy plan, through choosing Arenas, Vehicles, differentiators, Staging to Economic logic, is explained in Fig. 5 below, [12], [14], [18] :

4) Strategy development and Capability Analysis is conducted by providing each of the capabilities identified before with one sentence describing what the capability means to Faculty, Clustering similar capabilities into one capabilities group, example: e Learning and e back office become Internet Technology Utilization, defining each of the capabilities and conducting current organization capabilities analysis (OCA matrix), shown in Table IV and Fig. 6, [1], [10], [11], [14]-[17], [19], [20] .

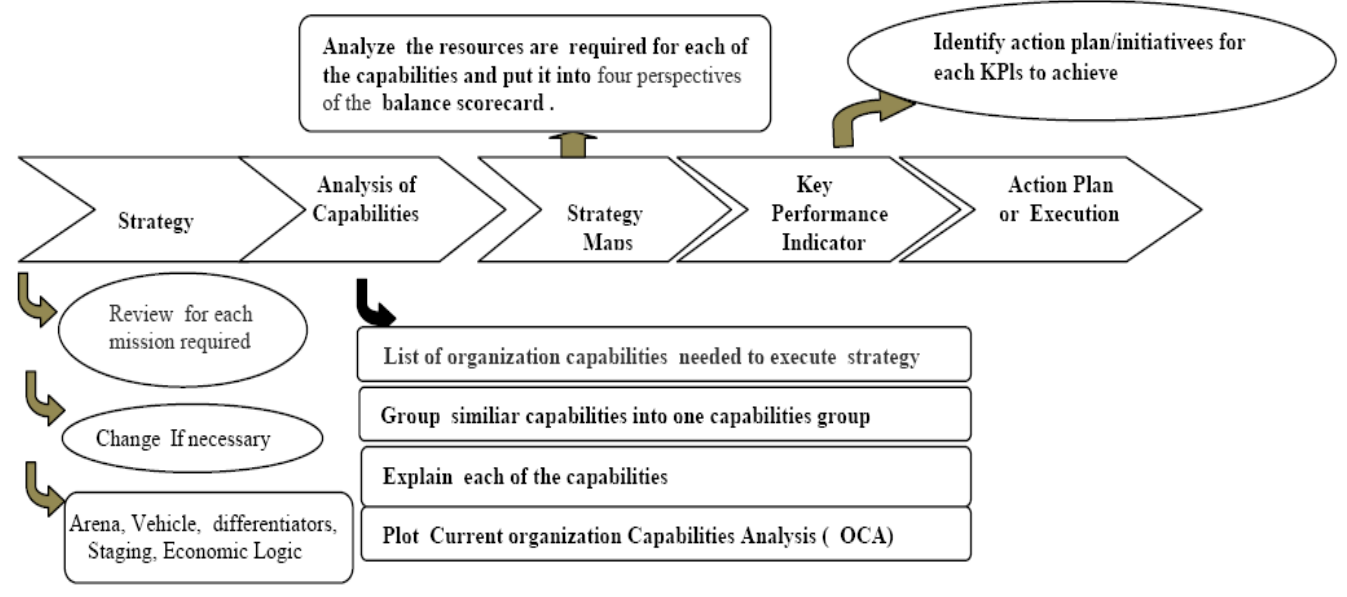

Fig. 5. Creating strategic direction

5) Then the results of clustering similar capabilities in Table $\mathrm{V}$ are plotted in Fig. 6 matrix corresponding to the objectives in Business and Management faculty of the sample used in this study. Furthermore, the strategy map was developed to facilitate monitoring and controlling as well as to assess the achievement of the strategy, as measured by identifying the KPIs for each perspective in the strategic map which are: the Learning \& Growth, Internal Process, Customer and Financial. The action plan is based on a desired institutional strategy. From Table V, it can be indentified that to implement the strategy with 58 organization capabilities (OC) are needed into 11 clustering similar capability from A to $\mathrm{K}$ shown in Fig. 6 .As condition, A to $\mathrm{K}$ OC plotted as below:

Based on the Table V, Faculty leader ( Dean) excutes the programs that put the priority on factor A,B,D,E,G,H,J and $\mathrm{K}$ as they are very crucial factors in achieving faculty internationalization program and the performance of these factors are stll low. As for C,I,K and F factors are important but the performance of this factors are average and need to improve through innovation so that it will become crucial factors.

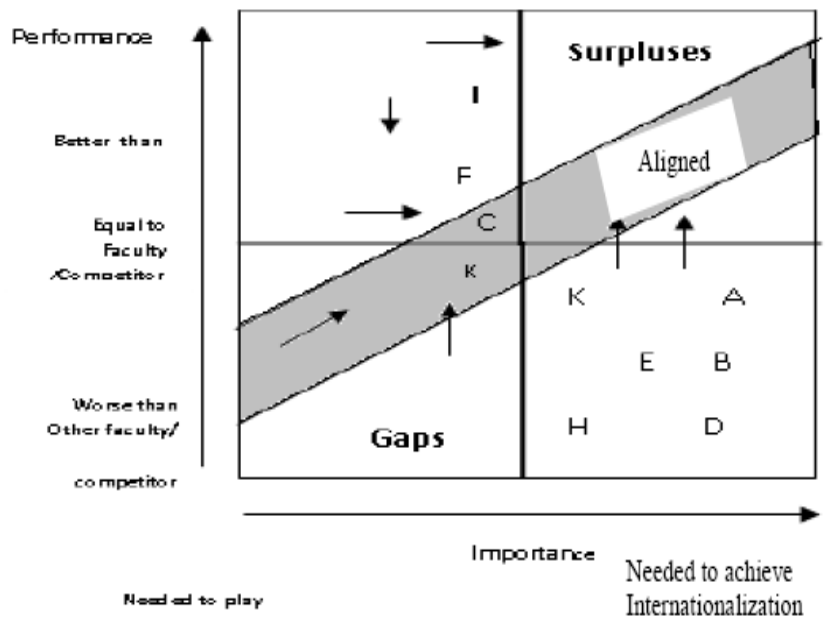

Fig. 6. Plot of Similar Organization Capabilities

TABLE V: CLUSTER SIMILAR ORGANIZATION CAPABILITY (OC)

\begin{tabular}{|c|c|}
\hline A. Organization \& Leadership :3,7,13,17,18,24,29,33,36,45,57,58 & $\begin{array}{l}\text { F. Research, Professional Service, Community Service: } \\
12,40,39,44,49,53\end{array}$ \\
\hline B. Managing Quality Management System : 4,19,20,21,26,35,39,40,41,44,51,54 & G. Cooperation \& Networking : 6,7,32,37,38,46,50,58 \\
\hline C. Student and Graduate : $25,26,31,32,34,35,49,50,52$ & H. ICT Utilization : $28,35,48,55$ \\
\hline D. Managing People at work : $13,14,22,23,26,36,43$ & $\begin{array}{l}\text { I. Funding, Facility \&Marketing Management : } 5,10,28,39 \text {, } \\
40,47,48,53,54\end{array}$ \\
\hline $\begin{array}{l}\text { E. Developing Curriculum, Learning Management System , \& } \\
\text { Academic Atmosphere: } 1,8,27,57,52\end{array}$ & $\begin{array}{l}\text { J. Creating \& managing KMS : 2,9,11,15,16,38,42. } \\
\text { K. Recognition \& National and International Accreditation }\end{array}$ \\
\hline
\end{tabular}


From Cluster Organization Capability which is the breakdown the internationalization strategy, a road map strategy can be developed through the development of 4 perspectives : learning \& growth, Internal process, Customer and Financial (see Fig. 7. )

Strategy maps are used to communicate their strategic plan clearly. Using this map a leadership team can explain how they expected to achieve success [1], [14], [21], [22].

TABLE IV: RESULT OF DEVELOPING STRATEGY AND ORGANIZATION CAPABILITY

\begin{tabular}{l}
\hline Five Elements \\
\hline \hline ARENA \\
a) Graduate Competency \\
b) Teaching \& Learning \\
Process \\
c) Research \\
d) Reward \\
\& recognize \\
accreditation \\
\\
\\
\\
\\
VEHICLES \\
a. ICT utilization \\
b. Quality Management \\
System (QMS) \\
c. Strengthening \\
partnership \& \\
Cooperation
\end{tabular}

\section{DIFFERENTIATORS}

a. Entrepreneurship Competency for graduates

b. Knowledge Worker c. Learning Organization d.International

Experience for student

\section{STAG I N G}

a) Integrated Internal Design System

b) External

\section{ECONOMIC LOGIC}

Impact customer value, graduates that work in global companies and as knowledge worker

Strategy

Organization Capability

1. Aplication KMS

2. Change Curricullum \& Learning process

3. Student Internship

4. Research enhancement in applied business

5. Reward recognize \& accreditation a) ICT for all process in University

b) Implementation QMS

c) Building partnership \& Cooperation
a) Internship Program for graduate
b) Soft Skill enhancement
c) Partnership \&Cooperation
d) Leadership enhancement
e) Design Knowledge based Organization

a) Enhancement \&Grow from Internal

b) Management then External Relationship in just 5 years

a) Increasing students enrollment

b) Graduates acceptance in global companies

c) Graduate Income

d) Trust, Fund Endowment

e) Core Competency Faculty
1) Designing curriculum to meet with internationalization program \& providing business practice. 2) Developing \& managing Knowledge Management System ( KMS ) integrated with Learning System; 3) Developing organization relationship clearly ; 4) Implementing Quality Management System (QMS) ; 5 ) Providing financial \& facility support for managing knowledge ;6) Creating Cooperation \& networking with business \& management school, industries; 7) Build and execute win-win strategic alliances; 8) Developing and/or acquiring learning methodologies, tools and techniques ;9)Converting individual tacit into enterprise explicit knowledge ; 10) Developing \& Managing facilities for Learning by doing ; 11) Creating an environment for collaborative knowledge sharing;12) Developing applied based research

13) Developing and training Leaders who are able to execute the programs \& Facilitate desired behavior and attitudes 14) national and international accreditation

15) Creating knowledge driven culture; 16) Managing KMS;

17) Developing learning organization ; 18) Developing Knowledge Community in the faculty ; 19) Developing processing management that are efficient and effective. ; 20) Providing KPIs for all business processes .21)Administer internal programs/policies cost-efficiently, with minimum distraction from the faculty focus ; 22) Developing Managing Knowledge worker ; 23) Align human resource assets, values, programs, and practices to support the business strategies; 24) Developing Leader with knowledge behavior ; 25) Creating customer value chains ; 26) Rewarding \& recognizing, quality \& knowledge award (best lecture award, best employee, best researcher, best student, best innovator award) ; 27) Creating and Developing E Learning /learning Management system ; 28) On Line Promotion, On Line Registration, on line test, Marketing survey 29) Devise aim and operating strategies to remain competitive 30) Cooperation with WCU; 31) Mobility student to other University (Internationalization)

32) Developing cooperation with alumni and industries for student Internship 33) Create identification and differentiation of corporate image in the customer's mind 34) Assessing graduates competency ; 35) Describing faculty Competency Faculty in E Learning, KMS, Quality Assurance, Decision making system, Intra staff Information system ; 36) Soft skill \& Leadership learning; 37) Alumni Cooperation ;

38) Managing the transfer of Knowledge to action and value (digital library, Journal, Blog conference, executive, Blog conference, executive information system, knowledge information system) ; 39) Involving Customers in the development product and service ;

40) Creating customer value chains

41) Managing Operation and Service ; 42) Developing \& managing work environment to share knowledge ; 43) Developing HR as Knowledge worker \& Competency based Compensation ; 44) Training for the workforce in innovation or ideas; 45) Creating learning Organization ;

46) Creating cooperation among relevant institutions

47) Marketing research,Promotion ; 48) Online registration; 49) Managing the production and/or services of knowledge-based goods and services ; 50) Developing cooperation with the companies and alumni for student Internship ; 51) Assessing the achievement of quality Objective ; 52) Developing graduates as knowledge based workers;

53) Transforming enterprise knowledge into shareholder value ;

54) Produce goods and services cost-effectively ; 55) Use technology to improve effectiveness and efficiency ; 56) Developing and Managing Key performance Indicator ; 57) Describing Faculty Competency Faculty and E Learning, KMS, Quality Assurance, system

58) Creating Executive Information system, Intra staff Information system 


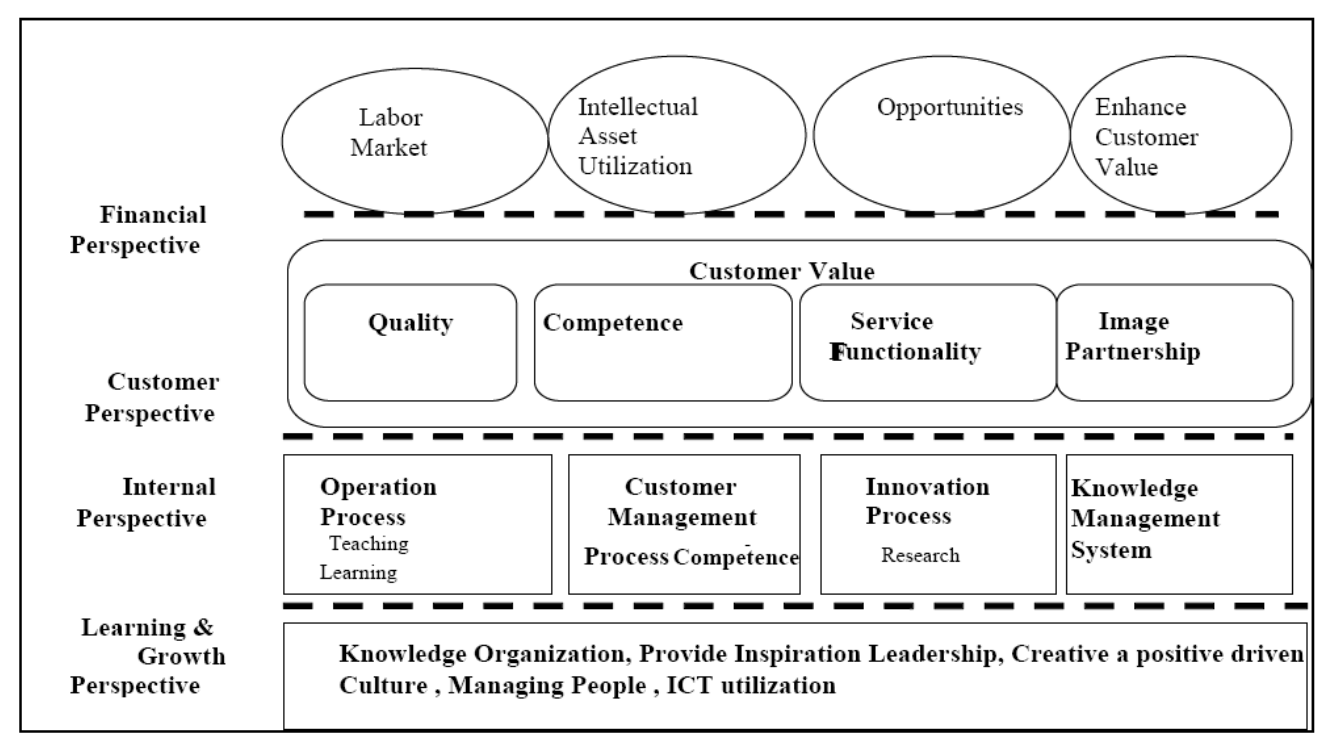

Fig. 7. Strategy map

\section{CONCLUSION}

In developing internationalization startegy in higher education, the important thing is to make sure the strategy was translated into annual operating plan for at least the first year. A critical test of a good strategic plan is that the operational implications are clear. The strategy process must have great leadership for driving organizational change and executing the strategy [5], [7], [23].

Time is needed to translate strategy into operational terms, which provide focus. These are then cascaded to all members of staff to support engagement and ownership. This can be difficult to achieve in practice, as there is an inevitable tendency for leaders and managers to concentrate their time on day-to-day activities in faculty as usual rather than engaging with the complexity of the 'strategy' map process.

HR plays important role in strategy implementation and developing an organization's competitive advantage.By increasing the competencies of HR personal, the department will increase its creditability and be integrated into a strategic role. In other words, HR resources are what drive an organizations' strategic process [1], [3], [23].

Then Culture, like strategy, is often viewed as an ephemeral construct. Culture change requires as clearly defined end state. Culture is the sum of set of shared values, values are composed of specifics beliefs. If you want change culture, change values, if you want change values, change beliefs and behaviors. [1], [20].

There are several important thing to need concern in Aligning Human Resource and University Strategy [8]- [1], [14], [20], [23].

1) Set the value which can be energy in running business strategy.

2) Translate business strategy into action plan. So that it can identify core competency which needed by organization business strategy, scorecard, and Key Performance Indicators (KPIs).

3) Human Resource is needed to knowing the different between Current Human Resource and business strategy needs.
4) Cascading Business Strategy and Human Resource function activity through CBHRM (Competency Based Human Resource Management)

5) Develop corporate culture and change management to execute the business strategy.

6) Build great leadership for driving organizational change and executing the business strategy.

Both the International Strategy and its Action Plan

Need to be seen as evolving documents. Successful internationalization is not simply a matter of promoting and developing income-generating opportunities. It is about preparing and enabling us all to become more effective global citizens.

\section{ACKNOWLEDGMENT}

No one walks alone on the journey of life. First and foremost, I would like to thank to Faculty Business \& Management Widyatama University for providing with valuable information to complete this study.

\section{REFERENCES}

[1] D. Kusumastuti, "Aligning Human Resource and Business Strategy," in Proc. International Seminar, Widyatama University \& De Lasalle Lippa University Philippine, theme: Improving Business Competitiveness through Integrated System, Indonesia ISBN: 978979-25-0221-3, 2011.

[2] L. T. Friedman, The World is Flat, A brief History of the Twenty First Century, Publisher Farrar, Straus \& Giroux, 1st Edition, ISBN 10-037429288-4, 2005.

[3] H. Linda, Aligning HR and Business strategy, Title 658.3, ISBN 0 750653620 Butterworth- Heinermann Edition, in acre House, Jordan Hill, Oxford OX2 8DP, 225 Wildwood, Avenue, Woburn, MA 01801-2041, A Publishing Ltd, pp. 360- 422, 2001.

[4] J. Knight. Internationalization of Higher Education practices and priorities. (2003). IAU Survey Report. [Online]. Available: http://www.unesco.org/iau/internationalisation.html.

[5] H. D. Wit, Internationalization of Higher Education in the US and Europe a Historical Comparative and Conceptual Analysis, Praeger Publisher, 2002.

[6] J. Salmi, The Challenge of establishing world-class university, ISBN 978-0-8123-7865-6, pp. 1-58, 2009.

[7] Z. Qiang, "Internationalization of Higher Education," Towards a conceptual framework, Policy Future in Education, vol. 1, no. 2, ISSN 1478-2103, 2003.

[8] N. Djaneva. The Internationalization of higher education in Kyrgyztan. (1998). [Online]. Available: http://condor.depaul.edu/rrotenbe/aeer/v17n2/Djanaaeva.pdf 
[9] S. Noorda, "Future business schools," Journal of Management Development, vol. 30, no. 5, pp. 519-525, 2011.

[10] AACSB, Globalization of management education: Changing International Structures, Adaptive Strategies, and the Impact on Institutions, Report of the AACSB International Globalization of Management Education Task Force, ISBN 978-0-85724-941-8, 2011.

[11] D. Kusumastuti and R. Agatha, "Globalization Business and Business Education," in Proc. the International Conference on Organizational Innovation, Airlangga University, Indonesia, International Proceeding, ISBN 97898685682 66, 2012, pp. 37.

[12] C. D. Hambrick and W. J. Frederickson, "Are you sure you have strategy," Journal Academy of Management Executive, vol. 4, no. 19, pp. 51-62, 2005.

[13] Self Evaluation Report year 2008-2011, Faculty of Business \& Management, Widyatama University - Indonesia.

[14] D. Kusumastuti and H. Prabowo, "Aligning of Knowledge Management and People Management," in Proc. International Conference in SEAAIR 2011, Chiang Mai, Thailand 2011, ISBN, Case of Private University in Indonesia, 2011, pp 112-118

[15] I. Nonaka and K. Takeuchi, The knowledge creating company: How Japanese companies create the dynamics of innovation, Publisher: Oxford University Press, USA, pp. 20-70, May, 1995.

[16] H. Prabowo, Encapsulation in University, Creating Sustainable Competitive Advantage Professorial Confirmation Seminar Monograph, Binus University Jakarta, Indonesia, 2009.

[17] K. W. Chan and R. Mauborgne, Blue Ocean Strategy, How to Create Uncostested Market Space and Make the Competition Irrelevant, Harvard Business School Press, 2005.

[18] Strategimanajemen. (July, 2011). [Online]. Available: http://strategimanajemen.net
[19] C. W. Choo, The Knowing Organization, How Organizations use Information to Construct Meaning, Create Knowledge, and Make Decisions, second Edition Published October 27th 2005 by Oxford University Press first published, January 8th 1998.

[20] W. H Bradley, The New Human Capital Strategy, Improving the value of your most important investment year after year, ISBN 13:978-0-8144-0927-5, АMACOM, Ny. 1009, pp. 128-236, 2008.

[21] R. S. Kaplan and P. D. Norton, The Balance scorecard: Translating Strategy into Action, ISBN 087584-651-3, Printed in the USA 1996.

[22] Ascendant Strategy Management Group. (December 2012). [Online]. Available: http://www.ascendantsmg.com-info@ascendant.

[23] L. Bossidy and R. Charan, Execution: The Discipline of getting things done, ISBN 1400-04617-3, Published by Crown Business, New York, pp. 57-226, 2002.

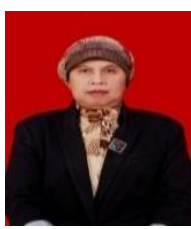

Dyah Kusumastuti has a doctor Management Education \& Policy from the University Pendidikan Indonesia (UPI), Master in Industrial Engineering \& Management. She is faculty member in the Department of Management of Private University in Indonesia. Research interest in Management Higher Education include Competency Based Human Resource Management, Asset Management. Besides above she is give professional services to government for Human resource Management system, Competency Assessment, Bureaucratic Reform. She has received awards and recognition from Government in the government capacity building. 